\title{
Weed suppression and soybean yield in a no-till cover-crop mulched system as influenced by six rye cultivars
}

\author{
M. Scott Wells ${ }^{1 \star}$, Carrie M. Brinton ${ }^{2}$ and S. Chris Reberg-Horton ${ }^{3}$ \\ 'Department of Agronomy and Plant Genetics, University of Minnesota, St. Paul, MN 55108, USA. \\ ${ }^{2,3}$ Department of Crop Science, North Carolina State University, Raleigh, NC, USA. \\ *Corresponding author: mswells@umn.edu
}

Accepted 29 August 2015; First published online 30 September 2015

Research Paper

\begin{abstract}
Cover crop mulches have been successful in reducing weed severity in organic soybeans. This study examined six rye cultivars (SRCs) used as cover crops to determine which were most adapted for use with a roller-crimper in the southeastern U.S. To be an effective mulch, a rye cultivar must produce high biomass and reach reproductive growth stage to facilitate mechanical termination via the roller-crimper prior to soybean planting. Rye cultivars were planted at three locations in North Carolina over the 2009 and 2010 growing seasons. Each rye cultivar was mechanically terminated via a roller-crimper implement. Rye cover crops were terminated on two dates and soybeans were immediately no-till planted into the mulch. In 2009, all rye cultivars produced greater than $9000 \mathrm{~kg} \mathrm{ha}^{-1}$ rye biomass dry matter (DM) with the exception of Rymin at Plymouth (2009), but in 2010 only the early flowering cultivars produced in excess of $9000 \mathrm{~kg} \mathrm{ha}^{-1}$ DM. There were no detectable soybean yield differences between the SRCs and the weed-free checks, and weed control was excellent across all SRCs at both Plymouth and Salisbury (2009). After an unseasonably cold and wet winter in 2010, the late flowering rye cultivars were not fully controlled by the early termination date due to delayed maturation (less than $65 \%$ control at 2 WAP) whereas the early flowering cultivars were fully controlled $\left(100 \%\right.$ control at 2 WAP). Rye biomass production was below $9000 \mathrm{~kg} \mathrm{ha}^{-1} \mathrm{DM}$ for the late flowering and dough development rye cultivars. The early-terminated rye plots had greater weed coverage across all SRCs than those from the late termination date $(P<0.01)$. However, weeds did not impact soybean yield for either of the termination dates. Soybean yield in 2010 was modeled with rye biomass and soybean population used as covariates, and for both termination dates, soybean yield was proportional to rye biomass production. Early flowering rye cultivars offer producers the widest range of termination opportunities that best coincide with their cash crop planting dates.
\end{abstract}

Key words: Cereal rye, conservation-tillage, no-till, cover crop, mulch, organic, rolled-crimped, rotational no-till, roller-crimper, soybean

In the absence of herbicides and transgenic crops, organic soybean producers must utilize a broad spectrum of techniques to control weeds. Intensive cultivation may be adequate in controlling weeds in organic soybeans, but the practice requires multiple timely passes (Place et al., 2009a) and weather-related delays to cultivation can lead to poor weed control. Cover crop mulches offer organic soybean producers an alternative approach that avoids energy-intensive and environmentally degrading tillage practices. In addition to providing organic soybean producers with alternative ecology friendly weed control, cover crops mulches are becoming a viable tool in conventional soybean productions systems where herbicide resistance prevents adequate weed control
(Price et al., 2012). The roller-crimper utilizes bluntedblades mounted on a drum cylinder, which flattens and crimps the cover crop without cutting the stems (Rodale Institute, 2012). For soybeans, cereal rye is typically the cover crop of choice due to its high biomass production, early maturity and allelopathic properties (Stoskopf, 1985; Reberg-Horton et al., 2005; Mirsky et al., 2009).

Rye mulches have been shown to be highly effective in reducing weed crop interference in soybeans and several mechanisms, both physical and chemical, contribute to the success of the system (Teasdale and Mohler, 2000; Davis, 2010; Wells et al., 2013). To be an effective weed barrier, rye mulches must exceed approximately 8000 $9000 \mathrm{~kg} \mathrm{ha}^{-1}$ dry matter (DM) production depending on 
the region where the cover crops are grown (Teasdale and Mohler, 2000; Smith et al., 2011). Unfortunately, levels of rye biomass can vary widely from year to year and factors such as establishment and termination dates (Mirsky et al., 2009, 2011) along with temperature and rainfall, can contribute to suboptimal rye biomass production (Travis et al., 1988; Mirschel et al., 2005). Regional microclimates can also influence the performance of the cover (e.g., rye) and cash crop, thereby increasing the importance of selecting the best-adapted rye cultivars and management strategies that optimize rye biomass potential that best corresponds to soybean planting dates for the Southeastern USA. Historically, farmers in the Southeastern USA have used early flowering winter-type rye cultivars. Presumably this choice was made to maximize biomass early both for the purpose of ground cover and grazing. However, the desired attributes for rye in a rolled-crimped system include high biomass at the time of soybean planting and rye that is sufficiently mature (soft dough, Feeke's 11.2) (Large, 1954) for successful mechanical termination thus synchronizing with soybean planting. Previous anecdotal information from the Southeastern USA, suggests that early flowering type rye cultivars may mature before the soil temperatures are warm enough for soybean planting (Personal communication: Chris Reberg-Horton, Organic Cropping System Extension Specialist). Organic farmers are particularly sensitive to soil temperatures at planting because of the lack of seed treatment. Conversely, if the late flowering-type rye cultivars mature too late the maturity group of the soybeans would need to be changed which has a multitude of implications for production.

Planting dates for organic soybeans in the Southeastern USA can vary based on the soybean maturity group and soybean producers have to balance pest and weed management needs. For example, soybean maturity Groups III and IV, considered early varieties, are planted in mid-May, and avoid many of the pest such as corn earworm at the cost of lower weed control (Dunphy et al., 2014). Typically double-cropped soybeans are planted mid to late June utilizing Group VI or VII (Dunphy et al., 2014).

The objective of this study was to find cereal rye cultivars best adapted to provide weed suppressive mulch for no-till soybeans in the Southeastern USA. Three early flowering and dough development ecotypes (Maton II, Wrens 96 and Wrens Abruzzi), and three late flowering dough development ecotypes (Aroostook, Rymin and Wheeler) were chosen. They were evaluated at two rolled-crimped termination dates for biomass, ease of kill, weed control and impact on soybean yield.

\section{Materials and Methods}

In 2009 and 2010, field experiments were conducted at three research stations in North Carolina, including
Salisbury and Plymouth (2009) and Kinston (2010). Plymouth and Kinston are located in one of the three major geographic regions of the NC: the Coastal Plain (Public Schools of North Carolina, 2015). The Coastal Plain is low, flat land along the Atlantic Ocean (Public Schools of North Carolina, 2015). Plymouth resides in the Tidewater region of the Coastal Plain and Kinston is located in the Inner Coastal Plain: a higher, drier area to the west of the Tidewater region (Public Schools of North Carolina, 2015). Salisbury resides in the major geographic region of NC referred to as the Piedmont. The Piedmont (i.e., 'foot of the mountain'), ranging in elevation from 91 to $457 \mathrm{~m}$ above the sea level, is the middle region of the state located between the Coastal Plain and Mountain regions (Public Schools of North Carolina, 2015). The three locations were selected to best reflect the regionality and predominate soybean production of the state.

The soil type at Salisbury was Lloyd clay loam (fine, kaolinitic, thermic Rhodic Kanhapludults) consisting of very deep, well-drained, moderately permeable soils on uplands in the Southern Piedmont, 2-8\% slope and moderately eroded. The soil types at Plymouth were Muchalee loam and Portsmouth fine sandy loam (fine-loamy over sandy or sandy-skeletal mixed, thermic, Typic Umbraquult). The soil type for Kinston was Johns loamy sand (course-loamy siliceous, semiactive, thermic, Arenic Hapludults) with 0-3\% slope.

The State Climate Office of North Carolina tracked weather data for all three-site years. Thirty-year average precipitation and air temperature were recorded along with monthly precipitation and air temperature for Salisbury and Plymouth (October 2008-October 2009) and Kinston (October 2009-October 2010) (Fig. 1).

Treatments were comprised six (fall planted wintertype) rye cultivars and two rye termination dates (e.g., early and late rolled-crimped dates) and subsequent soybean plantings via a no-till planter, all organized in a split-block design. Whole plot factors were rye termination dates, and sub-plot factors were the six rye cultivars (SRCs). Due to space limitations in 2009 at Plymouth and Salisbury there were four replicates present and in 2010 the Kinston location had six replicates. Experimental units comprised of SRCs, three early flowering types (Maton II, Wrens 96 and Wrens Abruzzi) and three late flowering types (Aroostook, Rymin and Wheeler) all terminated via the roller-crimper either early (e.g., early May) or late (e.g., late May to early June). In addition to the SRC (e.g., early and late termination dates) experimental units, there were three control treatments outside of the factorial structure: Rolled-crimped rye and no-till soybeans plus PRE and POST herbicide weed control (designated, $\mathrm{RC}+\mathrm{HB}$ ), no rye cover crop and no-till soybeans with $(\mathrm{NT}+\mathrm{HB})$ and without $(\mathrm{NT}-\mathrm{HB})$ PRE and POST herbicide weed control. The RC $+\mathrm{HB}$ check is a weed-free control used to approximate the soybean yield losses associated with lack of weed control exhibited in 

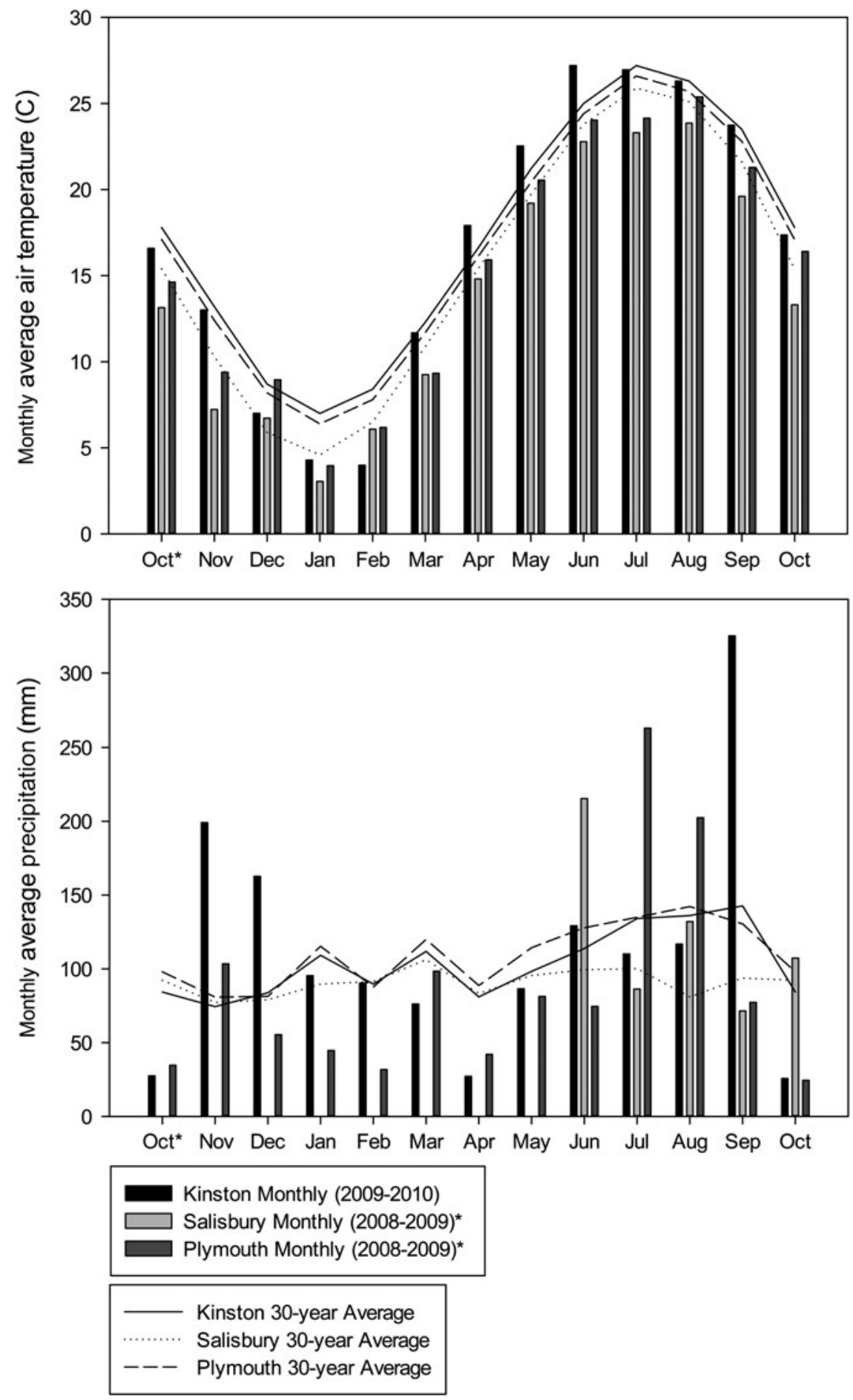

Figure 1. Average monthly precipitation (mm), air temperature (C) and 30-year normal for Plymouth, NC and Salisbury, NC (2009) and Kinston, NC 2010. Weather data provided by the State Climate Office of North Carolina.

the rolled-crimped rye treatments (i.e., RC-HB). The $\mathrm{NT}+\mathrm{HB}$ check functions to evaluate the loss of soybean yield associated with soybean grown in rye cover crop mulch. The NT-HB control also characterizes the weed severity for each site. Since the control treatments (e.g., with and without herbicide) were not fully crossed with the split-plot factor (e.g., rye cultivar),
Wrens 96 and Wheeler were selected to represent surrogates for the early and late flowering cultivar used in the $\mathrm{RC}+\mathrm{HB}$ control plots across all blocks. Wrens 96 selected for the early rye termination date, and Wheeler selected for the late rye termination date.

Prior to fall planting, all locations were disked with a tandem disk harrow to remove any existing vegetation. 
Lime, phosphorus and potassium were applied according to soil test recommendations prior to rye planting. To ensure that $\mathrm{N}$ fertility for the rye cover crop was adequate, the study areas at all locations received $30 \mathrm{~kg} \mathrm{ha}^{-1} \mathrm{~N}$ prior to fall cover crop planting and an additional $60 \mathrm{~kg} \mathrm{ha}^{-1} \mathrm{~N}$ top-dressed prior to joining in the spring. This amount of fertility is likely higher $\mathrm{N}$ than was needed for maximum rye growth (especially considering that the previous crop was corn), but was done to ensure that the system was tested under non-limiting conditions. Previous authors have noted large $\mathrm{N}$ carry over on farms with a long history of manure use (Engoke, 2012). Many organic producers in the Southeastern USA are able to achieve suggested biomass thresholds of optimal weed control through a combination of residual $\mathrm{N}$ from the previous crop and history of maturing, along with annual broadcasting of poultry litter (Personal communication: Chris Reberg-Horton, Organic Cropping Systems Extension Specialists).

All rye cultivars were direct seeded in the fall using a $152 \mathrm{~cm}, 8$ row, cone-drill (Wintersteiger Plotseeder, Wintersteiger Inc., 4705 Amelia Earhart Drive, Salt Lake City, UT 84116, USA) with $19 \mathrm{~cm}$ spacing between drill lines at $143 \mathrm{~kg} \mathrm{ha}^{-1}$ (Table 1). The plot size at all locations was $3 \mathrm{~m}$ wide by $15.2 \mathrm{~m}$ long. During the month of May and the first of June (corresponding to the early and late rye termination and soybean planting dates) all cultivars were terminated (i.e., rolled-crimped) based on the optimal planting schedule for the given soybean maturity group. At all locations the early dates corresponded with when soybean planting was occurring on nearby farms (Dunphy et al., 2014). Rye growth in development was monitored throughout the spring (data not presented) and the termination of the rye cultivars was delayed until the first instance of the soft-dough growth stage (Feeke's growth stage 11.2; Tables 1 and 3) was observed, thereby increasing both rye biomass accumulation and termination efficacy of the roller-crimper (Mirsky et al., 2009, 2011).

Following termination of the rye cover crops, soybeans (Glycine $\max$ L. 'NC Roy') of maturity group VI, were planted parallel to the drilled cover crop and rolling direction at 667,170 live seed ha ${ }^{-1}$ with $76 \mathrm{~cm}$ row spacing using a Monosem ${ }^{\circledR} \quad \mathrm{NG}$ Plus Vacuum planter (Monosem no-till planter, Monosem, Inc., 1001 Blake St., Edwardsville, KS 66111) equipped with Yetter Shark Tooth ${ }^{\circledR}$ residue managers (Yetter Profitable Solutions, P.O. Box 358, 109 S. McDonough, Colchester, IL 62326) to assist planting into the rye residue. Before soybeans were harvested via small plot combine (Wintersteiger Delta Small Plot Combine, Wintersteiger Inc., Salt Lake City, UT) in late fall to early winter, plots were trimmed to $12 \mathrm{~m}$ to minimize any potential edge effect. Soybean yield data were collected on the interior two rows.

The no-till without rye cover crop treatments received PRE burn down with glyphosate (Honcho ${ }^{\circledR}$ Plus, at
$0.85 \mathrm{~kg}$ a.i. $\mathrm{ha}^{-1}$, Monsanto Company, St. Louis, MO) to remove any weed coverage prior to soybean planting. In addition to the PRE burn down, weed free plots (with and without rye cover crop) were treated at planting for PRE weed control with S-metolachlor $\left(\right.$ Metal $^{\mathbb{B}}$ II, at $1.91 \mathrm{~kg}$ a.i. ha ${ }^{-1}$, Syngenta Crop Protection, Greensboro, NC). POST weed control in these plots was achieved with imazethapyr (Pursuit $^{\circledR}$, at 74.7 g a.i. ha ${ }^{-1}$, BASF Corporation, Raleigh, NC) applied 3-WAP. Hand weeding was done in addition to herbicide control as needed to ensure weed-free conditions throughout the season in $\mathrm{NT}+\mathrm{HB}$ and $\mathrm{RC}+\mathrm{HB}$ plots.

Crop parameters of interest for both early and late rolled-crimped termination dates included the growth stage of the rye cover crop, rye DM biomass production (on the day of crimping), percent rye control of the rye cultivars after rye termination and visually rated weed coverage at soybean growth stage R4. This stage occurred after soybean canopy closure. Along with the aforementioned parameters, soybean yield was also collected. On the same day the rye cultivars were rolled-crimped, a single rye biomass sample was harvested on a $0.5 \mathrm{~m}^{2}$ area from all plots and dried at $60^{\circ} \mathrm{C}$ with forced air for $72 \mathrm{~h}$. After the $72 \mathrm{~h}$ drying period, DM weights were recorded. Prior to rating the rye regrowth, all plots were visually assessed in order to give the evaluator a sense of relativeness. This procedure was performed at all locations. Rye regrowth was rated on a $0-100 \%$ scale, with $100 \%$ control representing no rye regrowth (e.g., 100\% of the rye was prostrate). Rye regrowth was visually rated 1-2 weeks after termination for both early and late rolled-crimped dates and soybean stand counts (i.e., populations) were counted on $1 \mathrm{~m}$ of soybean row. The number of weeds present was extremely low. Weed cover was used to quantify extremely low levels of weed competition. Weed cover was assessed in an area of $45.7 \mathrm{~m}^{2}$. For weed coverage, the scale is $0-100 \%$ and represents the percent of the ground covered. Only weeds above the soybean canopy were included in the coverage estimates. At the end of the season, soybeans were harvested with a plot combine, and yield, percent moisture and test weights were recorded.

The experiment was a split-block design with four blocks in 2009 and six blocks in 2010. Whole plot factors were rolled-crimped date (i.e., termination) and sub-plot factors were the SRCs. A combined analysis was attempted on the three site-years, but significant treatment by site-year interactions prevented a pooled analysis of soybean yield, rye biomass production and soybean populations (Table 2). Each site was analyzed separately with mean separation generated with Tukey's Honest Significant Difference (HSD) and pre-planned contrasts $(P<0.05)$. Due to large plot-to-plot variation concerning soybean population and rye biomass production, the Kinston 2010 yield data were modeled with two covariates, rye biomass and soybean population, included in the model. The Akaike information criterion (AIC) was 
Table 1. Dates for rye and soybean planting activities for Plymouth, Salisbury and Kinston for 2009-2010.

\begin{tabular}{llll}
\hline & & \multicolumn{2}{c}{ Rolled-crimped and soybean planting } \\
\cline { 4 - 4 } Site-years & Rye planting & Early & Late \\
\hline 2008-2009 & & & May-29 \\
Plymouth & Oct-3 & May-13 & Jun-2 \\
Salisbury & Sept-25 & May-21 & May-13 \\
2009-2010 & Oct-28 & May-6 & \\
\hline
\end{tabular}

Table 2. ANOVA generalized over site-years for soybean yield, rye biomass production, soybean population and percent weed coverage.

\begin{tabular}{lllll}
\hline & Rye biomass $^{1}$ & Soybean yield $^{\mathbf{1}}$ & Soybean population $^{\mathbf{1}}$ & \% Weed cover $^{\mathbf{2}}$ \\
\cline { 2 - 5 } Source & ANOVA & & & $*$ \\
\hline Rye termination date (D) & NS & NS & NS & $* *$ \\
Rye cultivar (C) & NS & NS & $*$ & NS \\
D $\times$ C & $*$ & NS & NS & NS \\
Site-year (S) & $*$ & NS & NS & - \\
S $\times$ C & NS & $* *$ & $* * *$ & - \\
S $\times$ D & NS & NS & $* * *$ & - \\
S $\times$ C $\times$ D & $P<0.10$ & &
\end{tabular}

${ }^{I}$ Soybean yield, rye biomass and soybean population averaged over all three site-years: Plymouth (2009), Salisbury (2009) and Kinston (2010).

${ }^{2}$ Weed control was excellent at Plymouth and Salisbury (2009) and percent weed cover is only analyzed for Kinston (2010).

$* * *$ and ${ }^{* * *}$ represent the significance of $F$ tests at $\alpha=0.05,0.01$ and 0.001 , respectively.

used for model selection (Johnson and Omland, 2004) in 2010 to determine whether the inclusion of covariates was justified.

\section{Results and Discussion 2009 Season}

Due to significant site-year by treatment interactions (Table 2), each site-year was analyzed separately. In 2009 at Plymouth, all rye cultivars were at or past the soft-dough growth stage (Feeke's Growth Stage 11.2) by the early rye termination date (Tables 1 and 3 ) resulting in $100 \%$ control across all rye cultivars (Table 3) (Mirsky et al., 2009, 2011; Wells et al., 2013). Similar trends were observed at Salisbury (2009), where four of the SRCs (Wrens 96, Wrens Abruzzi, Maton II and Aroostook) had matured to the soft-dough growth stage by the early rye termination date (May 21), thus resulting in 100\% (Table 3). Ashford and Reeves (2003) demonstrated effective termination of rye cover crops via a roller-crimper when the rye had entered late reproductive growth. During the early rye termination date in Salisbury, neither Rymin nor Wheeler, both late flowering types, were sufficiently mature for effective control with the roller-crimper as reflected by the observed lower control ratings of 25 and $65 \%$, respectively (Table 3). By the late termination date all cultivars were at or past soft dough at both locations, resulting in $100 \%$ control. Overall differences in time of flowering and dough development were less pronounced in 2009 than in 2010 .

No detectable termination date effect on rye biomass production was observed at either Salisbury or Plymouth (Table 4; Fig. 2). However, a significant $(P<$ 0.02 ) rye cultivar effect on biomass production at Plymouth was observed (Table 4). Rymin, a late flowering type, was the only rye cultivar at Plymouth that produced significantly less biomass $(P<0.05$; Fig. 2). In contrast, termination date, rye cultivar and the interaction impacted rye biomass production at Salisbury $(P<0.001$; Table 4; Fig. 2$)$. Even though the rye cultivars at Salisbury $(241 \mathrm{~m}$ above the sea level and USDA Hardiness Zone 7a) were planted earlier and terminated later than those at Plymouth ( $3.6 \mathrm{~m}$ above the sea level and USDA Hardiness Zone 7b) (Table 1), the monthly temperatures were lower at Salisbury when compared with Plymouth which significantly impacted the biomass of the rye cultivars in Salisbury (Fig. 1). This difference in rye maturity observed between Salisbury and Plymouth illustrates the importance of regional adjusted rye cultivars. 
Table 3. Mean percent control, a measure of rye regrowth, of SRC stands for two roll-dates, 2 weeks after soybean planting and Plymouth, Salisbury and Kinston, North Carolina.

\begin{tabular}{|c|c|c|c|c|c|c|c|}
\hline \multirow[b]{3}{*}{$\begin{array}{l}\text { Early rye term. } \\
\text { date }\end{array}$} & \multirow[b]{3}{*}{$\begin{array}{l}\text { Flowering } \\
\text { timing }^{1}\end{array}$} & \multicolumn{4}{|c|}{2009} & \multirow{2}{*}{\multicolumn{2}{|c|}{$\begin{array}{c}2010 \\
\text { Kinston }\end{array}$}} \\
\hline & & \multicolumn{2}{|c|}{ Plymouth } & \multicolumn{2}{|c|}{ Salisbury } & & \\
\hline & & $\begin{array}{c}\text { Growth } \\
\text { stage }^{2}\end{array}$ & $\begin{array}{l}\text { Percent } \\
\text { control }\end{array}$ & $\begin{array}{l}\text { Growth } \\
\text { stage }\end{array}$ & $\begin{array}{l}\text { Percent } \\
\text { control }\end{array}$ & $\begin{array}{c}\text { Growth } \\
\text { stage }\end{array}$ & $\begin{array}{l}\text { Percent } \\
\text { control }\end{array}$ \\
\hline Maton II & $\mathrm{EF}$ & 11.2 & 100 & 11.2 & $100 \mathrm{a}^{3}$ & 11.2 & $98 \mathrm{a}$ \\
\hline Wrens 96 & $\mathrm{EF}$ & 11.2 & 100 & 11.2 & $100 \mathrm{a}$ & 11.2 & $100 \mathrm{a}$ \\
\hline Wrens Abruzzi & $\mathrm{EF}$ & 11.2 & 100 & 11.2 & $100 \mathrm{a}$ & 11.2 & $98 \mathrm{a}$ \\
\hline Aroostook & LF & 11.2 & 100 & 11.2 & $100 \mathrm{a}$ & 11.0 & $65 \mathrm{~b}$ \\
\hline Rymin & LF & 11.2 & 100 & 11.1 & $25 \mathrm{~b}$ & 10.54 & $27 \mathrm{c}$ \\
\hline Wheeler & LF & 11.2 & 100 & 11.1 & $65 \mathrm{c}$ & 10.54 & $20 \mathrm{c}$ \\
\hline \multicolumn{8}{|c|}{ Late rye term. date } \\
\hline Maton II & $\mathrm{EF}$ & 11.3 & 100 & 11.4 & 100 & 11.3 & $100 \mathrm{a}$ \\
\hline Wrens 96 & $\mathrm{EF}$ & 11.3 & 100 & 11.3 & 100 & 11.3 & $100 \mathrm{a}$ \\
\hline Wrens Abruzzi & $\mathrm{EF}$ & 11.3 & 100 & 11.3 & 100 & 11.3 & $100 \mathrm{a}$ \\
\hline Aroostook & $\mathrm{LF}$ & 11.3 & 100 & 11.4 & 100 & 11.2 & $100 \mathrm{a}$ \\
\hline Rymin & $\mathrm{LF}$ & 11.3 & 100 & 11.2 & 100 & 11.1 & $75 \mathrm{~b}$ \\
\hline Wheeler & $\mathrm{LF}$ & 11.3 & 100 & 11.2 & 100 & 11.1 & $60 \mathrm{~b}$ \\
\hline
\end{tabular}

1 Relative flowering timing for winter-type rye cultivars.

2 Growth stage taken at rye termination dates using the Feeke's scale.

3 Means followed by the same letter are not significantly different based on Tukey's HSD test at $P<0.05$.

$\mathrm{EF}$, early flowering and dough development; LF, late flowering and dough development.

Early rye termination (Term.) date (via roller-crimper) for Plymouth, Salisbury and Kinston were May 13 and May 21, 2009 and May 6, 2010. The late rye termination date (via roller-crimper) for Plymouth, Salisbury and Kinston were May 29 and June 2 , 2009 and May 13, 2010.

Table 4. ANOVA for rye biomass production, soybean yield and soybean populations at site-years Plymouth (PLY), Salisbury (SAL) and Kinston (KIN).

\begin{tabular}{|c|c|c|c|c|c|c|c|c|c|}
\hline \multirow[b]{3}{*}{ Source } & \multicolumn{3}{|c|}{ Rye biomass } & \multicolumn{3}{|c|}{ Soybean yield } & \multicolumn{3}{|c|}{ Soybean populations } \\
\hline & \multicolumn{2}{|c|}{2009} & \multirow{2}{*}{$\frac{2010}{\text { KIN }}$} & \multicolumn{2}{|c|}{2009} & \multirow{2}{*}{$\begin{array}{l}2010 \\
\text { KIN }\end{array}$} & \multicolumn{2}{|c|}{2009} & \multirow{2}{*}{$\frac{2010}{\text { KIN }}$} \\
\hline & PLY & SAL & & PLY & SAL & & PLY & SAL & \\
\hline Rye termination date (D) & NS & NS & NS & $* *$ & $*$ & $*$ & NS & NS & $* *$ \\
\hline Rye cultivar $(\mathrm{C})$ & $*$ & NS & $* *$ & NS & NS & NS & NS & NS & NS \\
\hline $\mathrm{D} \times \mathrm{C}$ & NS & $* *$ & NS & NS & NS & NS & $*$ & NS & NS \\
\hline CV(RMSE) $(\%)$ & 23.5 & 8.9 & 21.8 & 19.5 & 18.9 & 13.8 & 16.3 & 6.9 & 25.9 \\
\hline \multicolumn{10}{|l|}{ Contrast } \\
\hline $\mathrm{RC}+\mathrm{HB}$ versus $\mathrm{SRC}$ & - & - & - & NS & NS & $P<0.09$ & $*$ & NS & $* *$ \\
\hline $\mathrm{NT}+\mathrm{HB}$ versus $\mathrm{RC}+\mathrm{HB}$ & - & - & - & NS & NS & NS & NS & NS & NS \\
\hline EL versus LF Rye cultivars & $P<0.08$ & NS & $* * *$ & NS & NS & NS & NS & NS & NS \\
\hline$(\mathrm{RC}+\mathrm{HB}$ versus $\mathrm{SRC}) * \mathrm{D}$ & - & - & - & NS & NS & NS & NS & NS & NS \\
\hline$(\mathrm{NT}+\mathrm{HB} \text { versus } \mathrm{RC}+\mathrm{HB})^{*} \mathrm{D}$ & - & - & - & NS & NS & $* *$ & $*$ & NS & $* * *$ \\
\hline (EF versus LF Rye cultivars)*D & $*$ & $* * *$ & NS & NS & NS & NS & NS & NS & NS \\
\hline
\end{tabular}

RC, rolled-crimped rye; SCR, six rye cultivars; EF, early flowering rye cultivars; LF, late flowering rye cultivars; HB, herbicide weed control; NT, no-till without rye cover crop mulch; CV(RMSE), coefficient of variation of the root-mean-squared error. $*, * *$ and ${ }^{* * *}$ represent significance of $F$ tests at $\alpha=0.05,0.01$ and 0.001 , respectively. North Carolina.

Sufficient rainfall and slightly below average temperatures occurred prior to both rye termination dates in 2009 , ensuring adequate soil moisture for soybean planting (Fig. 1). Soybean population was excellent in 2009 , and neither rye termination date nor rye cultivars impacted soybean populations at both Plymouth and Salisbury (Table 4). Mean soybean populations for Salisbury and Plymouth were 49 and 42 plants $\mathrm{m}^{-1}$, 


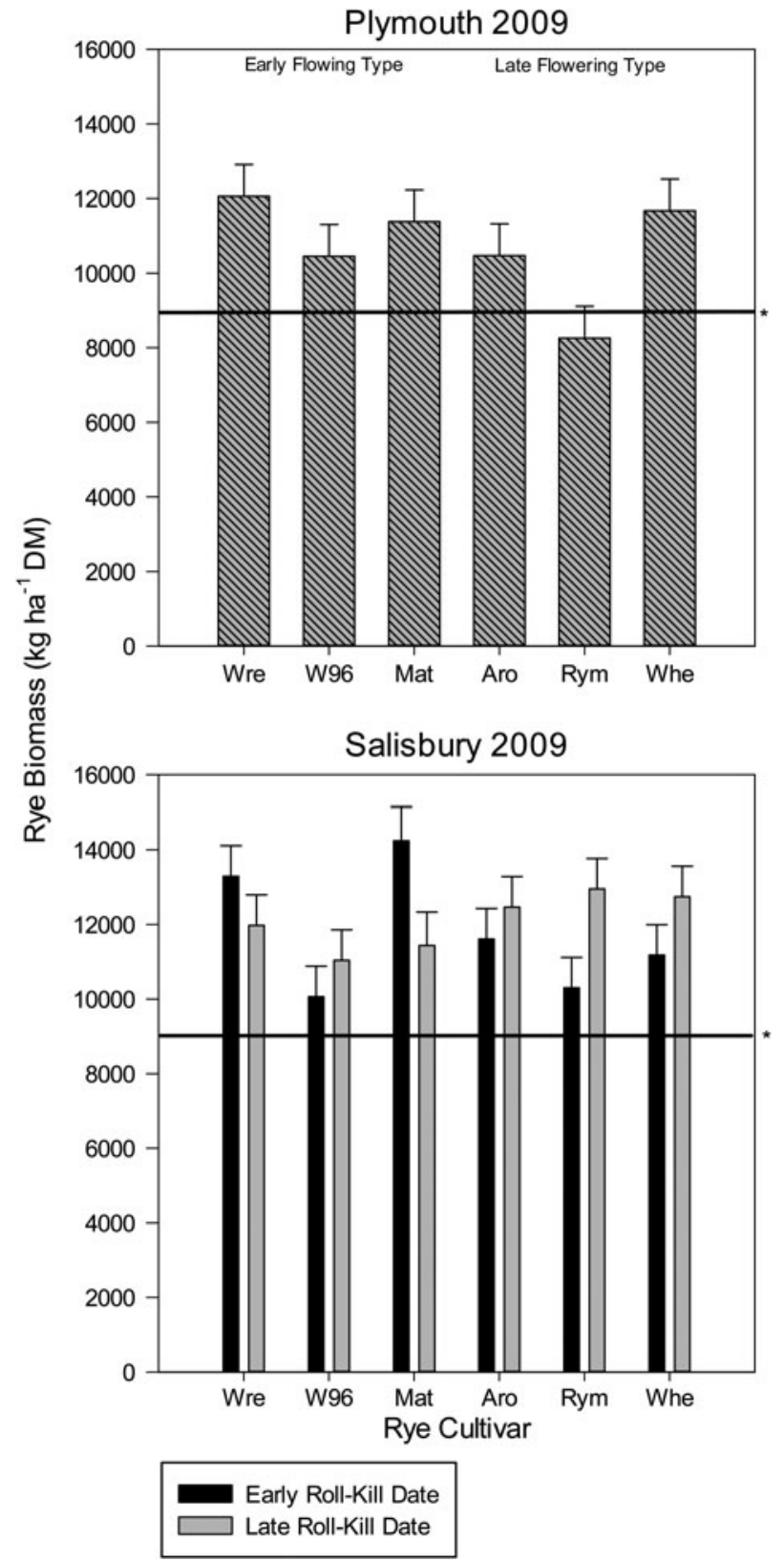

Figure 2. Mean rye biomass production for Plymouth and Salisbury, NC (2009). Winter type cereal rye cultivars are as follows: Wrens Abruzzi (Wre), Wrens 96 (W96), Maton II (Mat), Aroostook (Aro), Rymin (Rym) and Wheeler (Whe). Rye termination date was not significant for both Plymouth and Salisbury. Rye cultivar was significant in predicting biomass yield at Plymouth only $(P<0.02)$. The interaction of rye termination date by cultivar was significant at Salisbury $(P<0.001)$. Bars extend to +1 standard errors of the estimate. *Suggested biomass threshold for optimal weed control potential (Smith et al., 2011).

which correspond to 636,482 (95\% of targeted soybean populations) and 561,680 (84\% of targeted soybean populations) soybean plants per hectare, respectively (data not shown). Soybean populations did not significantly $(\alpha=$ $0.05)$ vary between the SRCs and the three checks at both locations for the early and late rye termination dates, and all populations for Salisbury and Plymouth were sufficient to successfully compete with in-row weeds (Place et al., 2009a). Along with excellent soybean populations in 2009 for both Plymouth (39-49 plants $\mathrm{m}^{-1}$ ) and Salisbury (48-52 plants $\mathrm{m}^{-1}$ ), rye biomass production across all cultivars (with the exception of Rymin at Plymouth) for both locations was above the suggested threshold for sufficient weed control for the Southeastern US soybean producers (Fig. 2) (Smith et al., 2011). Weed control was excellent at both Plymouth and Salisbury across all rye cultivars, as evidenced by the equivalent yields observed in the weed-free rolled rye plots $(\mathrm{RC}+\mathrm{HB})$ and the SRCs that had no additional weed control other than mulch (Tables 4 and 5).

\section{Season}

In 2010, rye termination date did not impact rye biomass production, however, the rye cultivars did significantly differ in biomass production $(P<0.001)$ (Table 4; Fig. 3). Wrens Abruzzi, Wrens 96 and Maton II all reached the suggested biomass threshold for optimal weed control $\left(9000 \mathrm{~kg} \mathrm{ha}^{-1}\right)$ for the Southeastern USA by the early rye termination date (Fig. 3). None of the late flowering type rye cultivars reached the $9000 \mathrm{~kg} \mathrm{ha}^{-1}$ threshold (Fig. 3). Overall, the late flowering cultivars produced less biomass (7412 $\left.\mathrm{kg} \mathrm{ha}^{-1} \mathrm{DM}\right)$ than early flowering $\left(9920 \mathrm{~kg} \mathrm{ha}^{-1}\right.$ DM; $P<0.001)$ cultivars and Rymin produced the lowest biomass of the six cultivars (6000 $\mathrm{kg} \mathrm{ha}^{-1}$ DM; Fig. 3).

The early flowering rye cultivars were all at the softdough stage (Feeke's 11.2) by the May 6th early rye termination date, whereas the late flowering types Aroostook, Rymin and Wheeler were not, with 65, 27.5 and 20\% control ratings, respectively 2-WAP (Table 3). Even by the later rye termination date, only Aroostook, a late flowering cultivar, achieved $100 \%$ control (i.e., $0 \%$ rye regrowth) via the roller-crimper, with Rymin and Wheeler still lagging behind at 75 and $60 \%$ control ratings, respectively (Table 3 ).

The weather trends at Kinston during the 2009-2010 cover crop growing season could offer some explanation as to the large cultivar differences observed. Kinston had 1.5 times more rainfall than the 30 -year average, with 200 and $160 \mathrm{~mm}$ of precipitation in November and December, respectively (Fig. 1). The combination of the unseasonably cold and wet winter and the exceptionally dry April, with only $25 \mathrm{~mm}$ of precipitation, could have greatly influenced the rye biomass potential (Fig. 1). Akemo et al. (2000) experienced similar climate conditions and reported poor rye growth of $1 \mathrm{Mg} \mathrm{ha}^{-1}$. The low water-holding capacity of the soil at Kinston (loamy sand) meant reduced water availability for optimum rye growth in the spring. Early flowering cultivars were near physiological maturity before the onset of the dry period, but late flowering cultivars were still vegetative (pre-boot; Table 3). 
Table 5. Soybean yield for Plymouth and Salisbury (2009).

\begin{tabular}{|c|c|c|c|c|}
\hline \multirow[b]{3}{*}{ Treatments $^{1}$} & \multicolumn{2}{|c|}{ Plymouth } & \multicolumn{2}{|c|}{ Salisbury } \\
\hline & Early rye termination date & Late rye termination date & Early rye termination date & Late rye termination date \\
\hline & \multicolumn{4}{|c|}{ Yield $\left(\mathrm{kg} \mathrm{ha}^{-1}\right)$} \\
\hline $\mathrm{NT}+\mathrm{HB}$ & 2169 & 1786 & 2320 & 2060 \\
\hline $\mathrm{RC}+\mathrm{HB}$ & 2356 & 2053 & 2478 & 1938 \\
\hline Wrens Abruzzi & 2087 & 2094 & 2476 & 2180 \\
\hline Wrens 96 & 1906 & 2075 & 2785 & 2189 \\
\hline Maton II & 2027 & 2041 & 1957 & 2048 \\
\hline Aroostook & 1776 & 1984 & 2375 & 2008 \\
\hline Rymin & 2326 & 2034 & 2140 & 1941 \\
\hline Wheeler & 2145 & 2015 & 2205 & 1860 \\
\hline
\end{tabular}

1 Treatments consist of the two weed-free checks, no-till without rye cover crop plus herbicide weed control $(\mathrm{NT}+\mathrm{HB})$, rolledcrimped rye plus herbicide weed control (RC + HB), and SRCs: three early flowering types (Wrens Abruzzi, Wrens 96 and Maton II) and three late flowering types (Aroostook, Rymin and Wheeler).

Washington (Plymouth) and Rowan (Salisbury) county mean soybean yields were reported by USDA, NASS North Carolina Field Office as 2625 and $2489 \mathrm{~kg} \mathrm{ha}^{-1}$, respectively. North Carolina.

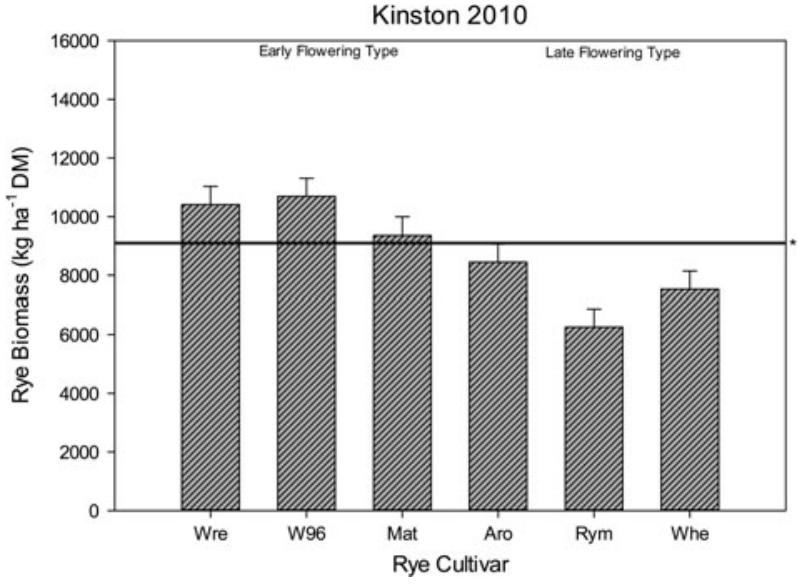

Figure 3. Mean rye DM biomass production for Kinston, NC (2010). Winter type cereal rye cultivars are as follows: Wrens Abruzzi (Wre), Wrens 96 (W96), Maton II (Mat), Aroostook (Aro), Rymin (Rym) and Wheeler (Whe). Rye cultivar was found to significantly predict rye biomass DM production $(P$ $<0.001)$. Rye termination date was not significant in predicting rye biomass DM production. Bars extend to +1 standard errors of the estimate. * Suggested biomass threshold for optimal weed control potential (Smith et al., 2011).

Soybean population counts also varied widely between rye termination dates in 2010 (Fig. 4) where rye termination date impacted soybean population (Table 4). The lack of precipitation throughout April and mid-May induced poor soybean stand quality during the early rye termination date (Figs 1 and 4). Planting conditions were drier and warmer than the 30-year average prior to the early rye termination date (Fig. 1), and soil moisture was limited for all treatments. The soil may have been drier in rolled-crimped plots due to transpiration of the cover crop both before and after the rye termination event, thereby lowering the available soil moisture. Ashford and Reeves (2003) observed similar depletion of soil water by a still-growing cover crop; which resulted in a reduction of soil moisture that could affect the emergence of the cash crop.

Soybean stand nearly doubled for the late rye termination date when compared with the early rye termination date 2010 (Fig. 4). All rye cultivars had soybean populations above 31 soybeans $\mathrm{m}^{-1}$ for the late rye termination date (Fig. 4). Prior to the late rye termination and planting date, Kinston received $38 \mathrm{~mm}$ of rainfall (Fig. 1). Unlike the dry conditions experienced prior to the early rye termination date, frequent rain events continued throughout the end of June, reducing the potential for drought stress.

Much like soybean populations, weed coverage at Kinston (2010) was variable across the two rye termination dates. Rye termination date and the interaction between rye cultivar and termination date affected the percent weed coverage at Kinston during the 2010 growing season (Table 2). The predominant weeds at Kinston included: redroot pigweed (Amaranthus retroflexus L.), morning glory (Ipomoea spp. L.), sicklepod (Cassia obtusifolia L.), horseweed [Conyza canadensis (L.) Cronq], texas panicum (Panicum texanum Buckl.), broadleaf signalgrass [Brachiaria platyphylla (Munro ex Wright) Nash] and large crabgrass (Digitaria sanguinalis (L.) Scop.).

Rye cultivar had no statistically significant $(\alpha=0.05)$ impact on post canopy weed coverage (Table 2); whereas rye termination date had a large effect on weed coverage $(P<0.05)$ (Table 2$)$. The early rye termination plots had greater weed coverage across all SRCs than those from the late rye termination date $(P<0.01)$. Maton II and Wheeler for the early rye termination date exhibited the lowest severity of weeds with only $20 \%$ weed coverage, whereas Wrens 96 had significantly 

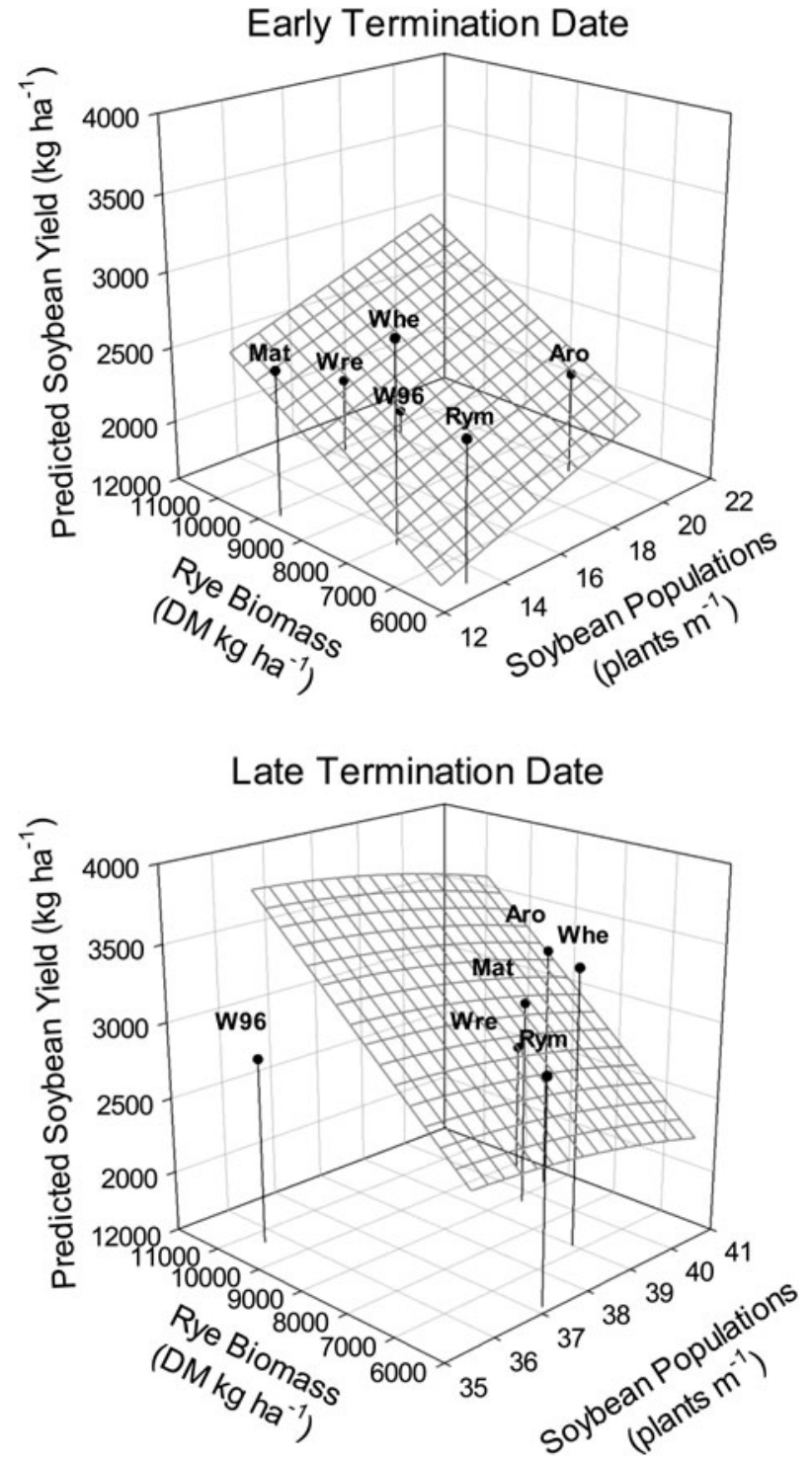

Figure 4. Soybean yield as predicted by soybean population and rye biomass production. Winter-type cereal rye cultivars are as follows: Wrens Abruzzi (Wre), Wrens 96 (W96), Maton II (Mat), Aroostook (Aro), Rymin (Rym) and Wheeler (Whe). The planes for both figures represent predicted soybean yield. Mean soybean yield as determined by soybean population and rye biomass production is overlaid with vertical drop down reference bars for each of the SRCs. The countywide soybean yield for Kinston, NC (2010) was $1,657 \mathrm{~kg} \mathrm{ha}^{-1}$ and provided by USDA, NASS North Carolina Field office.

higher $(P<0.05)$ weed coverage $(45 \%)$ (data not presented). All rye cultivars from the late rye termination date had similar weed coverage $(20 \%)$ as Maton II and Wheeler from the early termination date. The increased weed coverage observed for the early rye termination date are likely due to the reduced soybean population and lower levels of rye biomass. Increased crop populations have been shown to significantly reduce summer annuals, both in and between rows (Wiese et al., 1964; Place et al., 2009a).
Inadequate soybean stand establishment is an issue that impacts both in-row weed control, and can result in reduced soybean yields. When planting soybeans into rolled-crimped rye cover crop residues, several modifications to a no-till planter are necessary to effectively establish uniform soybean populations. One critical modification is the trash clearer which moves the weedsuppressive rye mulch away from the double-disc openers. This action minimizes hair-pinning of rye residues into the soybean furrow but at the cost of in-row weed control. Increase in soybean populations (i.e., more plants per linear row) have been shown as a viable in-row weed control practice that can compensate for the removal of the in-row weed-suppressive rye mulch (Place et al., 2009b). It is possible that the combination of a drier than normal spring, and the transpiration stress from the growing rye prior to and after termination, greatly reduced soil moisture reserves and subsequently the soybean populations thus releasing the in-row weeds from soybean competition and rye mulch weed control.

\section{Analysis of Covariance (ANCOVA)}

Soybean yield trends for Kinston 2010 were far more complex than those observed at the other locations. Soybean population and rye biomass production were found to be highly variable within treatments and residuals from the initial analysis of variance (ANOVA) were highly correlated with soybean yield; suggested covariates were necessary in the analysis. Rye biomass production was $84 \%$ more variable at Kinston when compared with Salisbury (Table 4). Kinston also had 45 and $115 \%$ greater variability (i.e., coefficient of variation of the root MSE) in soybean population when compared with Plymouth and Salisbury, respectively (Table 4), and population was likewise highly correlated with simple ANOVA residuals. With the inclusion of rye biomass and soybean population as covariates, rye cultivar was important in determining soybean yield at both the early and late rye termination dates (Table 6) whereas no differences had been significant in the simple ANOVA. Inclusion of both covariates provided better model fit (lower AIC) of the data than ANOVA. In addition to viewing these covariates as a means to reduce variation, their importance also may shed light on the role of these covariates in making the roller-crimper system effective.

In Model 1 of the early rye termination date, both soybean population and rye biomass positively affected soybean yield (Table 6; Fig. 4). It was not surprising that increases in soybean population and rye biomass both positively contributed to soybean yield (Fig. 4). Weed severity was of borderline importance in the simple ANOVA (RC $+\mathrm{HB}$ versus SRC, $P<0.09$ ), but this contrast showed no hint of significance on the ANCOVA (Table 6), suggesting the effect of weeds was mediated by one of the covariates. Since weeds did not significantly impact soybean yield, the only logical 
Table 6. Rye termination date ANCOVA and models predicting soybean yield for Kinston 2010.

\begin{tabular}{|c|c|c|c|c|c|}
\hline Early rye termination date & AICc & AIC & BIC & Estimate & $P>F$ \\
\hline Model 1* & 265.6 & 266.2 & 265.2 & & \\
\hline Intercept & & & & -47.62 & 0.03 \\
\hline Soybean population & & & & 2.19 & $<0.001$ \\
\hline Rye biomass & & & & 0.004 & 0.02 \\
\hline Rye cultivar & & & & - & 0.04 \\
\hline Soybean population $\times$ rye cultivar & & & & - & 0.65 \\
\hline \multicolumn{6}{|l|}{ Contrast } \\
\hline Roll-crimped rye $+\mathrm{HB}$ versus six rye cultivars & & & & & 0.42 \\
\hline Early versus late flowering cultivars & & & & & 0.06 \\
\hline \multicolumn{6}{|l|}{ Late rye termination date } \\
\hline Model 2* & 270.5 & 271.0 & 270.1 & & \\
\hline Intercept & & & & -127.67 & 0.21 \\
\hline Soybean population & & & & 8.23 & $<0.001$ \\
\hline Rye biomass & & & & 0.006 & 0.08 \\
\hline Rye cultivar & & & & - & 0.08 \\
\hline$(\text { Soybean population) })^{2}$ & & & & -0.14 & 0.18 \\
\hline \multicolumn{6}{|l|}{ Contrast } \\
\hline Roller-crimped rye $+\mathrm{HB}$ versus six rye cultivars & & & & & 0.30 \\
\hline Early versus late flowering cultivars & & & & & 0.02 \\
\hline
\end{tabular}

* Model chosen to predict Kinston 2010 soybean yield for 'Early and Late Rye Termination Dates'. North Carolina.

AICc, Akaike Information Criterion Correction; AIC, Akaike Information Criterion; BIC, Bayesian Information Criterion. The AICc, AIC and BIC statistics assist in model selection by providing a measure of relative quality of the statistical model. Lower values indicate increased statistical model quality. North Carolina.

conclusion was that below normal precipitation in 2010 and the addition of a rye cover crop were the likely culprits for reducing soybean population for the early-terminated rye cover crop treatments (Fig. 1). It is possible that demands on available soil moisture, already lower due to the lack of precipitation during the early rye termination and soybean planting date, was exacerbated by the transpiring rye cover crop both before and after termination. During the early rye termination date, the soybean populations for the NT + HB (i.e., no-till, weed free and without rye cover crop) were $60 \%\left(24\right.$ plants $\left.^{-1}\right)$ greater than the average of the SRCs $\left(15\right.$ plants $\left.\mathrm{m}^{-1}\right)$. However, it is important to note that even though soybean populations at Kinston were less than half those measured during the later termination date, soybean yields for the early termination date (Kinston 2010) were equivalent to those observed during the prior year at both Plymouth and Salisbury (40-45 plants $\left.\mathrm{m}^{-1}\right)$ (Table 5). Even though soybean yields were statistically equivalent across all cultivars in 2009, Wheeler, a late flowering rye cultivar, had the greatest soybean yield $\left(2915 \mathrm{~kg} \mathrm{ha}^{-1}\right)$ whereas Wrens 96 had the lowest $(1796 \mathrm{~kg}$ $\mathrm{ha}^{-1}$ ) among the SRCs in 2010 (Fig. 4).

Similar to the early rye termination date analysis, soybean population and rye biomass were highly variable between experimental units and both were selected as covariates to reduce the variability in the modeling of soybean yield for the late rye termination data (Table 6). Using the AIC, Model 2 was selected to best predict soybean yield (Table 6). Rye biomass, soybean stands count and rye cultivar affected soybean yield for the late rye termination date, whereas population*population contributed less to soybean yield (Table 6). For the late rye termination date (Model 2), weeds coverage did not reduce soybean yield as illustrated by the contrast $\mathrm{RC}+$ HB $\left(3515 \mathrm{~kg} \mathrm{ha}^{-1}\right)$ versus the SRCs $\left(2809 \mathrm{~kg} \mathrm{ha}^{-1}\right)$ (Table 6). Surprisingly, despite producing less rye biomass (Fig. 3), plots with late flowering rye cultivars produced greater average soybean yield than the modeled and the early flowering rye cultivars (Fig. 4). With the inclusion of the two covariates, the previous unexplained rye biomass production variation from the ANOVA as illustrated by the non-significant contrast 'Early versus Late Flowering Rye Cultivars' (Table 4) was accounted for and significantly impacted soybean yield in the ANCOVA setting (Table 6). Even though the late termination date was met with a rain event prior to termination, it is possible that the reduction of biomass production observed from the late flowering cultivars reduced the soil water deficit thereby requiring less precipitation to recharge the soil.

Soybean population was significant in predicting soybean yield for the late rye termination date (Table 6); however, a negative effect on soybean yield was observed as soybean populations increased (Fig. 4), which is in contrast to our earlier observations. The early rye termination plots during 2010 had extremely low soybean populations relative to target populations $\left(\mathrm{NT}+\mathrm{HB}, 22\right.$ plant $\mathrm{m}^{-1}$ and SRC, 15 plants $\mathrm{m}^{-1}$ ), whereas populations for the late rye termination date were nearly twice as dense 
$\left(\mathrm{NT}+\mathrm{HB}, 23\right.$ plant $\mathrm{m}^{-1}$ and SRC, 38 plants $\left.\mathrm{m}^{-1}\right)$. The rye mulch, combined with timely rainfall events, provided favorable conditions for optimal late soybean populations. However, during the hot and dry summer experienced in 2010 (Fig. 1), additional plants were likely a liability, with intraspecific competition reducing pod set and seed size (Specht et al., 1999; Heatherly and Elmore, 2004; Elmore, 2009; Walker et al., 2010). During the 2010 summer, greater drought stress was observed in the norye plots (i.e., NT $+\mathrm{HB}$ ) than the rye mulched plots where the terminated rye enhanced and augmented the soil moisture status resulting in nearly a $64 \%$ increase in soybean populations when compared with the NT $+\mathrm{HB}$ plots (Wells et al., 2014).

Analogous to previous research, this study demonstrates the flexibility of selecting the suitable rye cultivar to be used in the soybean/rolled-rye system. The early flowering rye cultivars performed the best across both years in regards to biomass production, percent control, weed control and subsequent soybean yield at all locations. Early flowering rye cultivars offer producers the widest range of termination opportunities that best coincide with their cash crop planting dates. Even in years with cold and wet winters followed by dry springs, as experienced in Kinston (2010), there are advantages to going with an early flowering rye cultivar such as delaying termination and planting until conditions are more favorable (Ashford and Reeves, 2003; Wells et al., 2014). In either case, producers should pick a rye cultivar with flowering and subsequent dough development dates that facilitate mechanical termination via the roller-crimper, and synchronize closely to the soybean planting date. One issue with utilizing early flowering rye cultivars is their lack of availability; therefore, further research is needed to quantify not only the advantages early flowering rye cultivars offer to soybean farmers in the Southeastern USA, but also the advantages that all regionally adjusted rye cultivars provide. Farmers are less likely to spend extra on named cultivars without knowing the services named cultivars offer above and beyond the less expensive nonstated cultivars.

Acknowledgments. Special thanks to the USDA NRCS Conservation Innovation Grant (CIG) for their continuing financial support. Along with the financial support from CIG, the expertise of North Carolina Department of Agriculture and Consumer Services research personnel from the following research stations was critical: Piedmont Research Center, Salisbury, NC; Tidewater Research Station, Plymouth, NC; and Caswell Research Farm, Kinston, NC.

\section{References}

Akemo, M.C., Regnier, E.E., and Bennett, M.A. 2000. Weed suppression in spring-sown rye (Secale cereale)-pea (Pisum sativum) cover crop mixes. Weed Technology 14:545-549.
Ashford, D.L. and Reeves, D.W. 2003. Use of a mechanical roller-crimper as an alternative kill method for cover crops. American Journal of Alternative Agriculture 18:37-45.

Davis, A.S. 2010. Cover-crop roller-crimper contributes to weed management in no-till soybean [electronic resource]. Weed Science 58:300-309.

Dunphy, J., Place, G., Dominic, R., and Reberg-Horton, S.C. 2014. Crop Production Management-Organic Soybeans [Internet]. NC State University Cooperative Extension; [cited 2015 Jun 6]. Available at Web site http://content.ces. ncsu.edu/chapter-5-crop-production-management-organic-soy beans/

Elmore, R. 2009. Assessing post-storm soybean stands [electronic resource]. Crop Watch, June 12, 2009.

Engoke, C.N. 2012. Verification of Poultry Manure Nitrogen Availability and Fertilizer Nitrogen Equivalence Coefficients for Crop Production in North Carolina Soils. dissertation. Raleigh, NC: North Carolina State University, Raleigh, NC.

Heatherly, L.G. and Elmore, R.W. 2004. Managing inputs for peak production. In H.R. Boerma and J.E. Specht (ed.). Soybeans: Improvement, Production and Uses. 3rd ed. Agron. Monogr. 16. ASA CSSA and SSSA, Madison, WI, p. 451 .

Johnson, J.B. and Omland, K.S. 2004. Model selection in ecology and evolution. Trends in Ecology \& Evolution 19:101.

Large, E.C. 1954. Growth stages in cereals. Illustration of the Feekes scale. Plant Pathology 3:129.

Mirschel, W., Wenkel, K.O., Schultz, A., Pommerening, J., and Verch, G. 2005. Dynamic phenological model for winter rye and winter barley. European Journal of Agronomy 23: 123-135.

Mirsky, S.B., Ryan, M.R., Shumway, D.L., Curran, W.S., and Mortensen, D.A. 2009. Control of cereal rye with a roller/ crimper as influenced by cover crop phenology [electronic resource]. Agronomy Journal 101:1589-1596.

Mirsky, S.B., Curran, W.S., Mortensen, D.M., Ryan, M.R., and Shumway, D.L. 2011. Timing of cover-crop management effects on weed suppression in no-till planted soybean using a roller-crimper. Weed Science 59:380-389.

Place, G.T., Reberg-Horton, S.C., and Burton, M.G. $2009 a$. Effects of preplant and postplant rotary hoe use on weed control, soybean pod position, and soybean yield. Weed Science 57:290-295.

Place, G.T., Reberg-Horton, S.C., Dunphy, J.E., and Smith, A.N. $2009 \mathrm{~b}$. Seeding rate effects on weed control and yield for organic soybean production. Weed Technology 23(4):497-502.

Price, A.J., Balkcom, K.S., Duzy, L.M., and Kelton, J.A. 2012. Herbicide and cover crop residue integration for amaranthus control in conservation agriculture cotton and implications for resistance management. Weed Technology 26(3):490-498.

Public Schools of North Carolina. 2015. K-12 Standards and Curriculum-Geography [Internet]. Available at Web site http://www.ncpublicschools.org/curriculum/socialstudies/ elementary/studentsampler/20geography.

Reberg-Horton, S.C., Burton, J.D., Danehower, D.A., Ma, G.Y., Monks, D.W., Murphy, J.P., Williamson, J.D., and Creamer, N.G. 2005. Changes over time in the allelochemical content of ten cultivars of rye (Secale cereale L.). Journal of Chemistry and Ecology 31:179-193.

Rodale Institute. 2012. No-till revolution. Available at Website http://rodaleinstitute.org/our-work/organic-no-till/ 
Smith, A.N., Reberg-Horton, S., Place, G.T., Meijer, A.D., Arellano, C., and Mueller, J.P. 2011. Rolled rye mulch for weed suppression in organic no-tillage soybeans. Weed Science 59:224-231.

Specht, J.E., Kumundini, S.V., and Hume, D.J. 1999. Soybean yield potential-a genetic and physiological perspective. Crop Science 39:1560-1570.

Stoskopf, N.C. 1985. Cereal Grain Crops. Prentice-Hall, Reston, VA.

Teasdale, J.R. and Mohler, C.L. 2000. The quantitative relationship between weed emergence and the physical properties of mulches [electronic resource]. Weed Science 48:385-392.

Travis, K.Z., Day, W., and Porter, J.R. 1988. Modelling the timing of the early development of winter wheat. Agriculture and Forest Meteorology 44:67-79.
Walker, E.R., Mengistu, A., Bellaloui, N., Koger, C.H., Roberts, R.K., and Larson, J.A. 2010. Plant population and row-spacing effects on maturity group III soybean. Agronomy Journal 102:821-826.

Wells, M.S., Reberg-Horton, S.C., Smith, A.N., and Grossman, J.M. 2013. The reduction of plant-available nitrogen by cover crop mulches and subsequent effects on soybean performance and weed interference. Agronomy Journal 105: $1-7$.

Wells, M.S., Reberg-Horton, S.C., and Mirsky, S.B. 2014. Cultural strategies for managing weeds and soil moisture in cover crop based no-till soybean production. Weed Science 62(3):501-511.

Wiese, A.F., Collier, J.W., Clark, L.E., and Havelka, U.D. 1964. Effect of weeds and cultural practices on sorghum yields. Weeds 12:209-211. 